Animal protein thus formed about $30 \%$ of the total protein intake.

During the second diet period the intake was raised by $500 \mathrm{Cal}$. from non-protein sources. The protein intake was kept unchanged. In the third diet period the protein intake was raised by adding $25 \mathrm{~g}$. animal protein/day usually as fish (canned pilchards or fresh fish). This raised the animal protein to about $50 \%$ of the total protein intake. The calorie intake rose by about $100 \mathrm{Cal}$. In the fourth diet period the protein content of the diet was raised by $20 \mathrm{~g}$. protein/day usually as fish but the total calorie intake was maintained at the level of the third period. Thus the percentage of animal protein rose to almost $70 \%$ of the total protein intake. During the fifth diet period the total calorie intake was raised by about $35^{\circ} \mathrm{Cal}$. but the total protein intake was maintained constant at the level of the fourth period.

\title{
Nutrition of Domestic Rabbits
}

\section{The Effect of Nutrition on the Carcass Composition of the Rabbit}

\author{
By J. C. D. HUTCHINSON \\ Small Animal Breeding Station and Department of Poultry Nutrition, \\ Animal Nutrition Institute, School of Agriculture, Cambridge
}

(Received I 5 August 1947)

It has long been known that different rates of growth when caused by differences in the amount of food eaten proföundly, affect the carcass composition of animals. Detailed studies on farm animals have been made by Moulton, Trowbridge \& Haig (1922) for cattle, by Vergés (1939) for sheep and by McMeekan (1940a, b, $c$ ) for pigs. Feeding ad lib. favours rapid growth of the late-developing parts of the animal, e.g. anatomically the loin or, chemically the deposition of fat, and therefore gives rapid maturity. Undernutrition stunts these late-developing parts because such food as is available for growth is used preferentially for those parts of the animal which are physiologically most important such as the skull and viscera. Undernutrition therefore produces a 'primitive' or late-maturing type of animal.

Many experiments have been carried out in which the effect of the qualitative nature of the ration on body composition has been investigated by chemical analysis of the whole carcass. In most cases the paired-feeding method was employed. With this technique the faster growing animal of a pair receives less food in relation to its requirements than its mate, and in general tends to lay down less fat in proportion to protein. This is especially true in the later stages of an experiment when one animal of a pair is considerably heavier than the other. Thus Mitchell \& Hamilton (1936) found that, with pigs and rats, as the protein level of the ration was raised to about $25 \%$, the proportion of fat to protein laid down decreased. Johnson, Hogan 
\& Ashworth (1936) in paired-feeding experiments with rats found that their animals gained more fat and less protein on a ration containing $10 \%$ protein than when the ration contained $26 \%$. Forbes, Swift, Black \& Kahlenberg (1935) and Forbes, Voris, Bratzler \& Wainio (1938) also found this to be the case between the levels of ro and $45 \%$ protein. Hamilton (1939), using the paired-feeding method for (a) equal feed and $(b)$ equal gain, found that below a level of $16 \%$ protein in the ration the ratio of energy to nitrogen of the carcass was increased. Beadles, Quisenberry, Nakamura \& Mitchell (1933), using the paired-feeding method with rats, found that a ration containing the protein of Limburger cheese as sole source of nitrogen produced carcasses of slightly higher energy content and less protein than one containing the same amount of rennet-curd milk protein, but the difference was small and not easily demonstrated. The protein of the Limburger cheese had a biological value $6 \%$ lower than that of the rennet curd. The biological value of protein may, therefore, as would be expected, affect carcass composition.

Two experiments are recorded, both on chicks, in which the effect of protein level was investigated when food intake was not controlled. Halnan (1942) fed three groups of chicks on a basal low-protein ration, and on this ration supplemented by whale meat dried by two different methods. With the basal ration the fat content of the gain in empty weight was $12.5 \%$, and with the two supplemented rations, 8.2 and $10.3 \%$, respectively; the protein contents were $16.4,19 \cdot 0$ and $18.1 \%$, and the average gains in empty weight in 5 weeks were 134,409 and $349 \mathrm{~g}$. Thus, although growth was considerably more rapid on the high-protein rations, the carcasses were chemically less mature than those of the birds which received the low-protein basal ration. This is the opposite of the result obtained when growth rate is controlled by altering the quantity, as opposed to the quality, of the ration (Moulton et al. 1922; Vergés, 1939; McMeekan, 1940a, $b, c$ ).

Fraps (I943) obtained similar results by varying the protein level in the ration. $\mathrm{He}$ found in addition that increasing the bulk with oat hulls reduced the fat in the carcass, but in this case growth was also reduced. Addition of oil to the ration gave fatter carcasses but growth was no greater.

McClure, Voris \& Forbes (1934), using the paired-feeding method, found that the carcasses of rats which received vitamin $B_{1}$ contained more fat than those which were deficient, although the growth rates of the two groups were about the same. Here again chemical maturity was unrelated to the rate of growth.

Kennard, Holder \& White (I922) found that addition of a mineral mixture to a basal ration deficient in minerals gave greater protein and less fat deposition. Deficiency in minerals can therefore also affect carcass composition.

During the war of $1939-45$ experiments were carried out in this laboratory on the efficiency of various natural rations for meat production in domestic rabbits. Amongst these experiments was one with two groups of rabbits, fed on different rations, of which the growth rate was very nearly the same while their fat deposition was widely different, and the results of this experiment are described in this paper. 
EXPERIMENTAL

\section{Genetic history of the animals}

All animals had the same sire of mixed Flemish-Giant and Belgian-Hare breeds. They were the offspring of five does of the same breeding. Offspring of all the does, except one, were represented in both groups. In addition three animals had litter-mates in the opposite group. The numbers of the mothers of the animals used for the experiment are included in Table 2.

\section{Plan of experiment}

The animals were fed from birth till weaning on a stock ration of cereals and protein concentrates with hay, carrot and cabbage. When they weighed approximately $1000 \mathrm{~g}$. (at 7-8 weeks) they were placed on the experimental rations in individual hutches and were fed for 7 weeks, except for animal no. 92 which was fed for 9 weeks. They were then starved for $24 \mathrm{hr}$., slaughtered and the carcasses were analysed for edible matter.

\section{Stock ration}

\section{Rations}

The stock ration had the following percentage, composition: maize meal $25^{\circ} \mathrm{O}$,

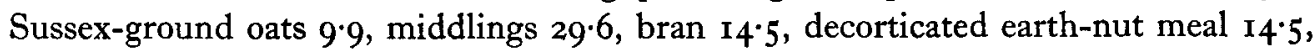
dried brewer's yeast 5.3 , sodium chloride 0.2 , bone meal 0.5 , calcium carbonate 0.5 . In addition $0.5 \%$ cod-liver oil was given and fresh cabbage or carrot and hay ad lib. The concentrate ration was made up into pellets in a pelleting machine. All animals were given water.

\section{Weed ration}

The weed-fed group received weęds only. About $70 \%$ of the weeds consisted of sow thistles, which are much more palatable than other species, but considerable quantities of shépherd's purse were fed, and small quantities of other species of weeds. Blocks of common salt were put in the hutches and water was always available.

\section{Potato ration}

All the potato-fed group received cooked potatoes and hay ad lib. and ro g. carrot daily. Two animals received $100 \mathrm{~g}$. cabbage/day. Four of the eight animals received supplements of casein. All received $0.5 \% \mathrm{NaCl}$ on the dry-matter basis, and water was always available. Details of the food intake of the two groups are given in Table $\mathrm{r}$. The casein was steamed with a little starch to make a cake which the animals would eat up quickly without scattering.

\section{Carcass analysis}

The animals were slaughtered by dislocating the neck, and put in cold storage. The dressed carcass, feet, pelt, kidneys, liver, total edible offal (brain, tongue, kidneys, heart) and inedible offal (excluding gut content) were weighed. The dressed-carcass weight was taken as the weight of the carcass after removal of the pelt, inedible offal, 
edible offal and feet. Care was taken to minimize evaporation during dissection by covering the carcass with wet cloths and working as quickly as possible. Dissection losses ranged from $\circ$ to $2 \cdot 5 \%$. The fat round the kidney and that over the shoulders and the pubic region (other dissected fat) was removed from the carcass and weighed.

\section{Table I. Food intake of rabbits during the feeding trial}

\begin{tabular}{|c|c|c|c|c|}
\hline Rabbit no. & $\begin{array}{l}\text { Potato dry matter } \\
\text { (g.) }\end{array}$ & $\begin{array}{c}\text { Total dry matter } \\
\text { (g.) }\end{array}$ & Protein (g.) & $\begin{array}{l}\text { Protein in dry } \\
\text { matter }(\%)\end{array}$ \\
\hline \multicolumn{5}{|c|}{ Potato-fed group* } \\
\hline 66 & 3005 & 4988 & 844 & $x 6 \cdot 9$ \\
\hline 67 & 3959 & 5885 & 944 & $16 \cdot 0$ \\
\hline 69 & 3785 & 4966 & 488 & $9 \cdot 8$ \\
\hline 73 & 2112 & 3642 & 335 & $9 \cdot 2$ \\
\hline 74 & 2236 & $52 \times 1$ & 789 & $15 \cdot 1$ \\
\hline 75 & 2570 & $46_{3} 8$ & 619 & 13.3 \\
\hline 81 & $36 r 0$ & 5047 & 583 & $1 \times \cdot 6$ \\
\hline 86 & 3062 & 4794 & 543 & II $\cdot 3$ \\
\hline Mean & 3042 & 4896 & 643 & $12 \cdot 9$ \\
\hline \multicolumn{5}{|c|}{ Weed-fed group } \\
\hline 80 & - & 5209 & 970 & 18.6 \\
\hline 84 & - & 3939 & 759 & $19 \cdot 3$ \\
\hline 85 & - & 4452 & 834 & 18.7 \\
\hline 92 & - & $701 \mathrm{r}$ & 1300 & 18.5 \\
\hline 100 & - & $476_{3}$ & $99 \mathrm{I}$ & 20.8 \\
\hline 104 & - & 4392 & 933 & $2 x \cdot 2$ \\
\hline 108 & - & 5167 & 1102 & $21 \cdot 3$ \\
\hline $\mathrm{Ir}_{4}$ & - & 5325 & 1238 & $23 \cdot 2$ \\
\hline II 6 & - & 3871 & 987 & 25.5 \\
\hline II 8 & 一 & 5299 & 1278 & $24 \cdot \mathrm{I}$ \\
\hline Mean & - & 4944 & 1039 & $2 I \cdot I$ \\
\hline
\end{tabular}

* Animals nos. 66,67 and 74 received a supplement of $20 \mathrm{~g}$. casein daily, and animal no. 75, $10 \mathrm{~g}$. Animals nos. $8 \mathrm{I}$ and 86 received $100 \mathrm{~g}$. cabbage daily.

This fat was analysed separately from the rest of the meat. The remainder of the carcass was cooked in a pressure cooker for $15 \mathrm{~min}$. and the edible matter was then removed from the bones for analysis. The meat was minced and dried and was then analysed for protein (total $\mathrm{N} \times 6 \cdot 25$ ) by the Kjeldahl method and for fat by ether extraction. The gross energy was obtained by calculation, taking for protein a value of $5.7 \mathrm{Cal} . / \mathrm{g}$. and for fat 9.46 Cal./g. (Breirem, I935).

To obtain an estimate of the initial carcass composition of the rabbits at weaning, a group of six weaned rabbits $7-8$ weeks old and closely related genetically to the experimental animals was killed and the carcasses were analysed in a similar manner. These animals had received the same stock ration which the potato-fed and weed-fed groups were given up to the time of weaning. In estimating the increase in edible matter of these latter groups during the feeding trial, the average amount of edible matter/unit weight of the baby rabbits was multiplied by the individual weights of the animals at the start of the trial. The figures obtained were taken as the initial amount of edible matter in the carcasses of the animals. The increase in edible matter was calculated by subtracting the estimated initial edible matter from the edible matter found at the end of the experiment. The estimate of initial edible matter is not strictly 
correct because the chemical composition of the carcass changes with increasing size of the animal. However, there was no correlation between the live weight and composition of the baby rabbits analysed; moreover, the composition of baby rabbits at about rooo g. live weight is not very variable. Therefore, although the potato-fed group was heavier than the other group at the beginning of the feeding trial, there was no evidence that this introduced a bias in the estimation of their relative production of edible matter.

\section{RESULTS}

Fig. I gives the mean growth curves of the two groups up to 14 weeks and also of a further group of closely related animals (all of them from the same litters) which were fed on the stock ration throughout. The two experimental groups grew at very nearly the same rate from birth to slaughter. The rate of growth was about three-quarters of

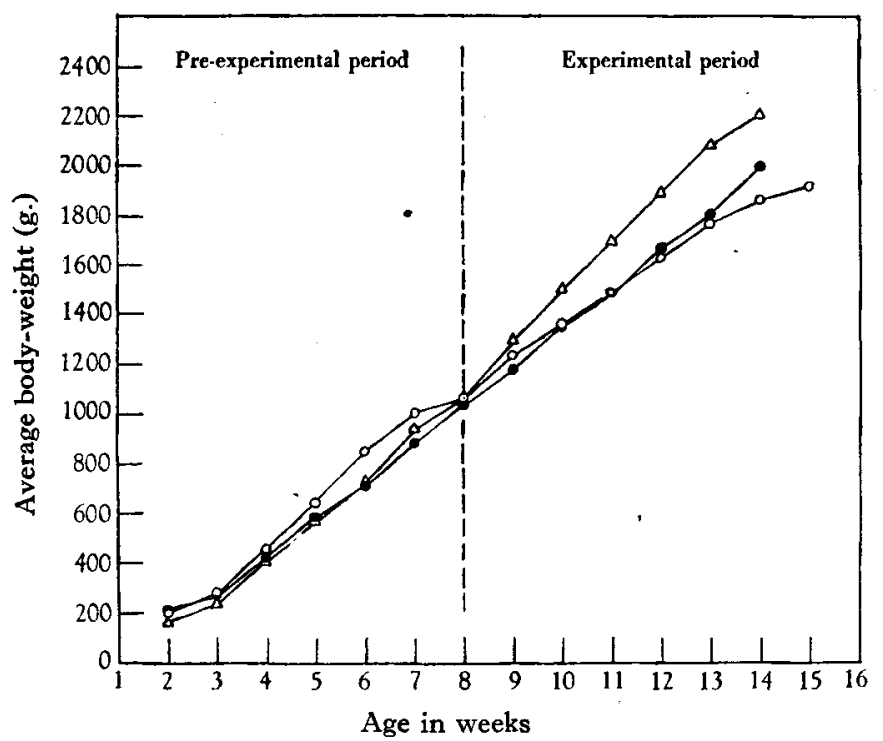

Fig. I. Composite growth curves of three groups of rabbits fed on a stock ration up to weaning and thereafter on the following three rations: cooked potatoes and hay (with a casein supplement in some cases), weeds only, and a stock ration. The vertical dotted line indicates the approximate age of weaning. $\mathrm{O}-\mathrm{O}$ Potatoes and hay ( + casein in some cases); $-\longrightarrow$ weeds; $\triangle-\triangle$ stock ration.

the maximum rate as shown by the growth curve of animals fed on the stock ration throughout. Of the two experimental lots the potato-fed group grew rather faster up to weaning, while the weed-fed group made the greater gains after weaning. If carcass composition depended only on growth rate one would expect that either the carcass composition of the two groups would be approximately the same, or that the weed-fed group would lay down rather more fat because it grew faster than the other group at the latter end of the feeding period at an age when fat deposition is normally active. Table 2 gives the growth of the individual animals during the experimental feeding period, the estimated initial dressed-carcass weight and the final dressed-carcass weight. Table 3 gives the weight of kidney fat, fat removed from over the shoulders 
Table 2. Live weights and dressed-carcass weights of rabbits which received the potato ration and the weed ration

\begin{tabular}{|c|c|c|c|c|c|c|c|}
\hline \multirow[b]{2}{*}{$\begin{array}{c}\text { Rabbit } \\
\text { no. }\end{array}$} & \multirow[b]{2}{*}{$\begin{array}{c}\text { Mother } \\
\text { no. }\end{array}$} & \multicolumn{3}{|c|}{ Live weight } & \multicolumn{3}{|c|}{ Dressed-carcass weight* } \\
\hline & & $\begin{array}{l}\text { Initial } \\
\text { (g.) }\end{array}$ & $\begin{array}{l}\text { Final } \\
\text { (g.) }\end{array}$ & $\begin{array}{l}\text { Gain in } \\
\text { 7.weeks } \\
\text { (g.) }\end{array}$ & $\begin{array}{l}\text { Estimated } \\
\text { initial } \\
\text { (g.) }\end{array}$ & $\begin{array}{c}\text { Final } \\
\text { (g.) }\end{array}$ & $\begin{array}{c}\text { Gain in } \\
7 \text { weeks } \\
\text { (g.) }\end{array}$ \\
\hline \multicolumn{8}{|c|}{ Potato-fed group } \\
\hline 66 & $\mathbf{B}_{2}$ & 1342 & 1882 & $54{ }^{\circ}$ & $69 \mathrm{I}$ & I 186 & 495 \\
\hline 67 & $\mathrm{~B}_{2}$ & 1136 & 2034 & 898 & 585 & 1219 & 634 \\
\hline 69 & $B_{2}$ & I 348 & I 975 & 627 & 694 & I 185 & 491 \\
\hline 73 & $\mathrm{~B}_{4}$ & ro86 & I 575 & 489 & 559 & 904 & 345 \\
\hline 74 & $\mathrm{~B}_{4}$ & 1147 & 2157 & roro & 591 & 1253 & 662 \\
\hline 75 & $\mathbf{B}_{I}$ & 1035 & 1814 & 779 & 533 & 968 & 435 \\
\hline $8 \mathrm{i}$ & $\mathrm{B}_{3}$ & 1150 & 2008 & 858 & 592 & 1138 & 546 \\
\hline 86 & $\mathrm{Br}_{\mathrm{I}}$ & 954 & 1636 & 682 & 491 & 961 & $47^{\circ}$ \\
\hline Mean & - & 1149 & 1885 & 735 & 592 & 1102 & 510 \\
\hline \multicolumn{8}{|c|}{ Weed-fed group } \\
\hline 80 & $\mathbf{B}_{3}$ & 1092 & I988 & 896 & 562 & I I 2 I & 559 \\
\hline 84 & $B_{I}$ & 978 & I536 & 558 & 504 & 888 & 384 \\
\hline 85 & $\mathbf{B}_{\mathbf{I}}$ & 1042 & 1696 & 654 & 537 & 911 & .374 \\
\hline 92 & $\mathbf{B}_{\mathbf{I}}$ & 910 & I993 & 1083 & 469 & I 195 & 721 \\
\hline 100 & B7 & 867 & г 894 & 1027 & 447 & 1079 & 632 \\
\hline 104 & $B_{7}$ & 863 & 1759 & 896 & 444 & 989 & 545 \\
\hline I08 & $\mathbf{B}_{2}$ & 997 & 2060 & $106_{3}$ & $51_{3}$ & I 167 & 654 \\
\hline $\mathrm{II}_{4}$ & $\mathbf{B}_{4}$ & 1 36 & 2152 & 1006 & 585 & 1280 & 695 \\
\hline II 6 & $\mathrm{~B}_{4}$ & 1020 & I956 & 936 & 525 & IOII & 486 \\
\hline 118 & $\mathrm{~B}_{4}$ & $95 \mathrm{I}$ & 2026 & 1075 & 490 & I 248 & $75^{8}$ \\
\hline Mean & - & 986 & I906 & 920 & 508 & 1088 & $5^{81}$ \\
\hline
\end{tabular}

Weight of carcass after removal of the pelt, inedible offal, edible offal and feet.

'Table 3. Dissection data for carcasses of rabbits which received the potato ration and the weed ration

\begin{tabular}{|c|c|c|c|c|c|c|c|c|c|c|}
\hline $\begin{array}{c}\text { Rabbit } \\
\text { no. }\end{array}$ & $\begin{array}{c}\text { Kidney } \\
\text { fat } \\
\text { (g.) }\end{array}$ & $\begin{array}{l}\text { Other } \\
\text { dissected } \\
\text { fat* } \\
\text { (g.) }\end{array}$ & $\begin{array}{c}\text { Feet } \\
\text { (g.) }\end{array}$ & $\begin{array}{l}\text { Pelt } \\
\text { (g.) }\end{array}$ & $\begin{array}{l}\text { Kidneys } \\
\text { (g.) }\end{array}$ & $\begin{array}{l}\text { Liver } \\
\text { (g.) }\end{array}$ & $\begin{array}{c}\text { Total } \\
\text { edible } \\
\text { offal } \\
\text { (g.) }\end{array}$ & $\begin{array}{c}\text { In- } \\
\text { edible } \\
\text { offal } \\
\text { (g.) }\end{array}$ & $\begin{array}{l}\text { Killing out } \\
\text { percentage } \\
\text { on live } \\
\text { wt. } \dagger\end{array}$ & $\begin{array}{c}\text { Killing out } \\
\text { percentage } \\
\text { on empty } \\
\text { wt. }\end{array}$ \\
\hline \multicolumn{11}{|c|}{ Potato-fed group } \\
\hline 66 & $31 \cdot 4$ & 23.4 & 25.0 & 262 & $14 \cdot 2$ & $5 \times \cdot 0$ & $82 \cdot 0$ & I 56 & 63.0 & $68 \cdot \mathrm{I}$ \\
\hline 67 & $22 \cdot 6$ & $25 \cdot 2$ & $29 \cdot I$ & 259 & $\times 4.9$ & $48 \cdot 3$ & $80 \cdot 4$ & $\times 59$ & 59.9 & $68 \cdot 5$ \\
\hline 69 & $26 \cdot 3$ & $29 \cdot 3$ & $28 \cdot 1$ & 247 & 14.8 & $58 \cdot 0$ & $88 \cdot 3$ & 176 & $59 \cdot 9$ & $67 \cdot 6$ \\
\hline 73 & 14.8 & $20 \cdot I$ & 27.5 & I 59 & $9^{\circ} 0$ & 35.5 & $62 \cdot 6$ & I 50 & $57 \cdot 3$ & 68.0 \\
\hline 74 & ro.9 & 40.8 & 30.5 & $23 \mathrm{I}$ & $18 \cdot 9$ & $78 \cdot 8$ & II 9.0 & 204 & $58 \cdot I$ & 66.5 \\
\hline 75 & $2 \cdot 9$ & $6 \cdot 2$ & $3 r \cdot 6$ & 211 & $14 \cdot 3$ & $70 \cdot 5$ & rog.3 & I75 & $53 \cdot 3$ & $65 \cdot 3$ \\
\hline 81 & $32 \cdot 2$ & $37 \cdot 2$ & $28 \cdot 5$ & 225 & $12 \cdot 7$ & $80 \cdot 0$ & 110.8 & 160 & $56 \cdot 7$ & $64 \cdot 9$ \\
\hline 86 & 15.5 & I 9.4 & $29 \cdot I$ & 176 & $\mathrm{II} \cdot 3$ & $53 \cdot 7$ & 83.3 & 167 & $58 \cdot 7$ & $66 \cdot 2$ \\
\hline Mean & $20 \% 7$ & $25 \cdot 2$ & $28 \cdot 7$ & 221 & $13 \cdot 8$ & $59 \cdot 5$ & $9 \pi \cdot 9$ & 168 & $58 \cdot 4$ & $66 \cdot 9$ \\
\hline \multicolumn{11}{|c|}{ Weed-fed group } \\
\hline 80 & $8 \cdot 7$ & 5.0 & $3 I \cdot 2$ & 268 & 15.9 & $65 \cdot 2$ & $98 \cdot 3$ & I 79 & $5^{6 \cdot 3}$ & $64 \cdot 9$ \\
\hline 84 & $1 \cdot 3$ & 0.8 & $25^{\circ} 0$ & 206 & I3. I & $52 \cdot 5$ & 80.7 & r29 & 57.8 & 65.3 \\
\hline 85 & 0.0 & 0.0 & $29 \cdot 7$ & 197 & 14.2 & $51 \cdot 2$ & $80 \cdot 9$ & 144 & $53 \cdot 7$ & 647 \\
\hline 92 & II $\cdot 0$ & I $3 \cdot 0$ & $28 \cdot 8$ & 244 & 15.9 & $62 \cdot 2$ & $96 \cdot 9$ & 170 & $60 \cdot 0$ & $66 \cdot 2$ \\
\hline 100 & 5.5 & $5 \cdot 3$ & $36 \cdot 0$ & 274 & r6. 1 & 510 & $88 \cdot 3$ & 186 & $56 \cdot 9$ & $64 \cdot 3$ \\
\hline 104 & $7 \cdot 3$ & $4 \cdot 6$ & 30.5 & 242 & $16 \cdot 5$ & $59 \cdot 6$ & $98 \cdot 9$ & 175 & $56 \cdot 2$ & 63.9 \\
\hline 108 & $6 \cdot 0$ & $7 \cdot 3$ & 33.3 & $26 \mathrm{I}$ & 15.8 & 53.4 & $86 \cdot 9$ & 187 & $56.7^{\circ}$ & 659 \\
\hline 114 & $8 \cdot 8$ & 14.8 & 36.8 & 283 & 19.0 & $73^{\circ} 0$ & 11 $2 \cdot 5$ & 212 & 59.5 & $66 \cdot 3$ \\
\hline 116 & $4 \cdot 2$ & $3 \cdot 2$ & $30 \cdot 7$ & 248 & 18.6 & $63 \cdot I$ & 102.9 & 178 & $51 \cdot 7$ & $64 \cdot 3$ \\
\hline 118 & 14.7 & $12 \cdot 0$ & $27 \cdot 2$ & 282 & $14 \cdot 6$ & 79.0 & $\operatorname{III} \cdot 8$ & 189 & $61 \cdot 6$ & $67 \cdot 8$ \\
\hline Mean & 6.8 & $6 \cdot 6$ & 30.9 & $25 \mathrm{I}$ & $16 \cdot 0$ & $61 \cdot 0$ & $95 \cdot 8$ & $x 75$ & $57 \cdot 0$ & $65 \cdot 4$ \\
\hline
\end{tabular}

* Fat from over the shoulders and the pubic region.

+ Dressed-carcass weight expressed as a percentage of weight of animal. 
and pubic region (other dissected fat), feet, pelt, kidneys, liver, total edible offal, inedible offal and killing out percentage on live weight and empty weight. The killing out percentage is the dressed-carcass weight expressed as a percentage of the total weight of the animal. Table 4 gives the chemical composition of the edible matter of the dressed carcasses comprising dry matter, protein, 'dissected fat' (kidney fat and fat removed from over the shoulders and the pubic region combined), total fat and gross

Table 4. Composition of the edible matter of dressed carcasses of rabbits which received the potato ration and the weed ration

\begin{tabular}{|c|c|c|c|c|c|}
\hline $\begin{array}{c}\text { Rabbit } \\
\text { no. }\end{array}$ & $\begin{array}{l}\text { Dry matter } \\
\text { (g.) }\end{array}$ & $\begin{array}{l}\text { Protein } \\
\text { (g.) }\end{array}$ & $\begin{array}{c}\text { Dissected fat* } \\
\text { (g.) }\end{array}$ & $\begin{array}{l}\text { Total fat } \\
\text { (g.) }\end{array}$ & $\begin{array}{l}\text { Gross energy } \\
\text { (Cal.) }\end{array}$ \\
\hline \multicolumn{6}{|c|}{ Potato-fed group } \\
\hline 66 & 309.4 & I $83 \cdot 3$ & $37 \cdot 8$ & $113 \cdot 7$ & 2119 \\
\hline 67 & 314.7 & $200 \cdot 3$ & $34 \cdot 5$ & III 2 & 2192 \\
\hline 69 & $316 \cdot 7$ & $176 \cdot 9$ & $40 \cdot 2$ & $127 \cdot x$ & 2209 \\
\hline 73 & 215.5 & $143 \cdot 0$ & $22 \cdot 7$ & $66 \cdot 3$ & $\mathrm{r} 44^{\circ}$ \\
\hline 74 & 319.9 & I94.I & $42 \cdot 9$ & $121 \cdot 6$ & 2256 \\
\hline 75 & 165.4 & $133 \cdot 8$ & $4 \cdot 8$ & $26 \cdot 7$ & IOI 5 \\
\hline 81 & $3 \times 1 \cdot 2$ & $182 \cdot 0$ & $5 x \cdot 5$ & $125 \cdot 1$ & 2218 \\
\hline 86 & $222 \cdot 3$ & $157 \cdot 7$ & $21 \cdot 2$ & $59^{\circ} 0$ & $\Upsilon 455$ \\
\hline Mean & $27 I \cdot 9$ & $17 I \cdot 4$ & $3 I \cdot 9 \pm 5 \cdot 3 t$ & $93.8 \pm 13.4 \uparrow$ & I 863 \\
\hline $\begin{array}{l}\text { Mean/rooo g. } \\
\text { dressed-carcass wt. }\end{array}$ & $246 \cdot 7$ & I $55^{\circ} 5$ & $28 \cdot 9$ & $85 \cdot 1$ & 1690 \\
\hline \multicolumn{6}{|c|}{ Weed-fed group } \\
\hline 80 & $228 \cdot 6$ & $178 \cdot 0$ & $6 \cdot 7$ & $4 I \cdot 7$ & 1407 \\
\hline 84 & $164 \cdot 7$ & $140: 3$ & 0.4 & $18 \cdot 7$ & 976 \\
\hline 85 & $159^{\circ} 6$ & $149 \cdot 3$ & 0.0 & $5 \cdot I$ & 898 \\
\hline 92 & $257^{\circ} 0$ & $197 \cdot 8$ & $14: 2$ & $46 \cdot 7$ & I 568 \\
\hline 100 & $216 \cdot 6$ & 167.0 & $5 \cdot 8$ & $36 \cdot 6$ & $\mathbf{2} 98$ \\
\hline IO4 & I95.9 & $147 \cdot 7$ & $7 \cdot 2$ & 347 & II6g \\
\hline ro8 & $240 \cdot 2$ & $191 \div 5$ & $6 \cdot 3$ & $3^{8 \cdot 6}$ & 1455 \\
\hline I 14 & $298 \cdot 3$ & $219^{\circ} 1$ & $13 \cdot 8$ & $74^{\circ} 0$ & I 946 \\
\hline I 16 & 198.6 & $163 \cdot 8$ & $4 \cdot I$ & 33.6 & 1251 \\
\hline 118 & 280.9 & 196.2 & $18 \cdot 3$ & $77 \cdot 7$ & $185 \mathrm{I}$ \\
\hline Mean & $224^{\circ} \circ$ & $175^{\circ} \circ$ & $7 \cdot 7 \pm 1 \cdot 9 \dagger$ & $40.7 \pm 7.0 t$ & $x_{3} 82$ \\
\hline $\begin{array}{l}\text { Mean/I000 g. } \\
\text { dressed-carcass wt. }\end{array}$ & $206 \cdot 6$ & $160 \cdot 8$ & $7 \cdot 0$ & $37 \cdot 4$ & 1269 \\
\hline
\end{tabular}

* Sum of kidney fat and fat removed from over the shoulders and the pubic region.

$\uparrow$ Standard error of the mean.

energy. Table 5 gives the increase in edible matter during the feeding trial. Table 6 gives the weights of the joints of meat (including bone) as a percentage of the dressedcarcass weight after removal of kidney fat and of the fat dissected from over the shoulders and the pubic region.

The final live weights of the two groups at killing were very nearly the same and, since there was but little difference in the killing out percentage, the final dressedcarcass weights were also the same. Similarly, there was no significant difference in the weight of liver, inedible offal and feet. The kidney weight tended to be less in those animals of the potato-fed group which received no casein supplement than in the remainder of the group. The pelts of the weed-fed group were slightly heavier than those of the potato-fed group. If the pelt weights are expressed as a percentage of the 
live weight, this difference is statistically significant $(P=0.01)$ although litter differences are estimated as error in applying the simple $t$-test. In the fatty tissue round the kidney and in that over the shoulders and the pubic region (other dissected fat) there was a very marked difference between the two groups. With the exception of rabbit no. 75

Table 5. Estimated gains in edible matter of dressed carcasses of rabbits during the feeding trial

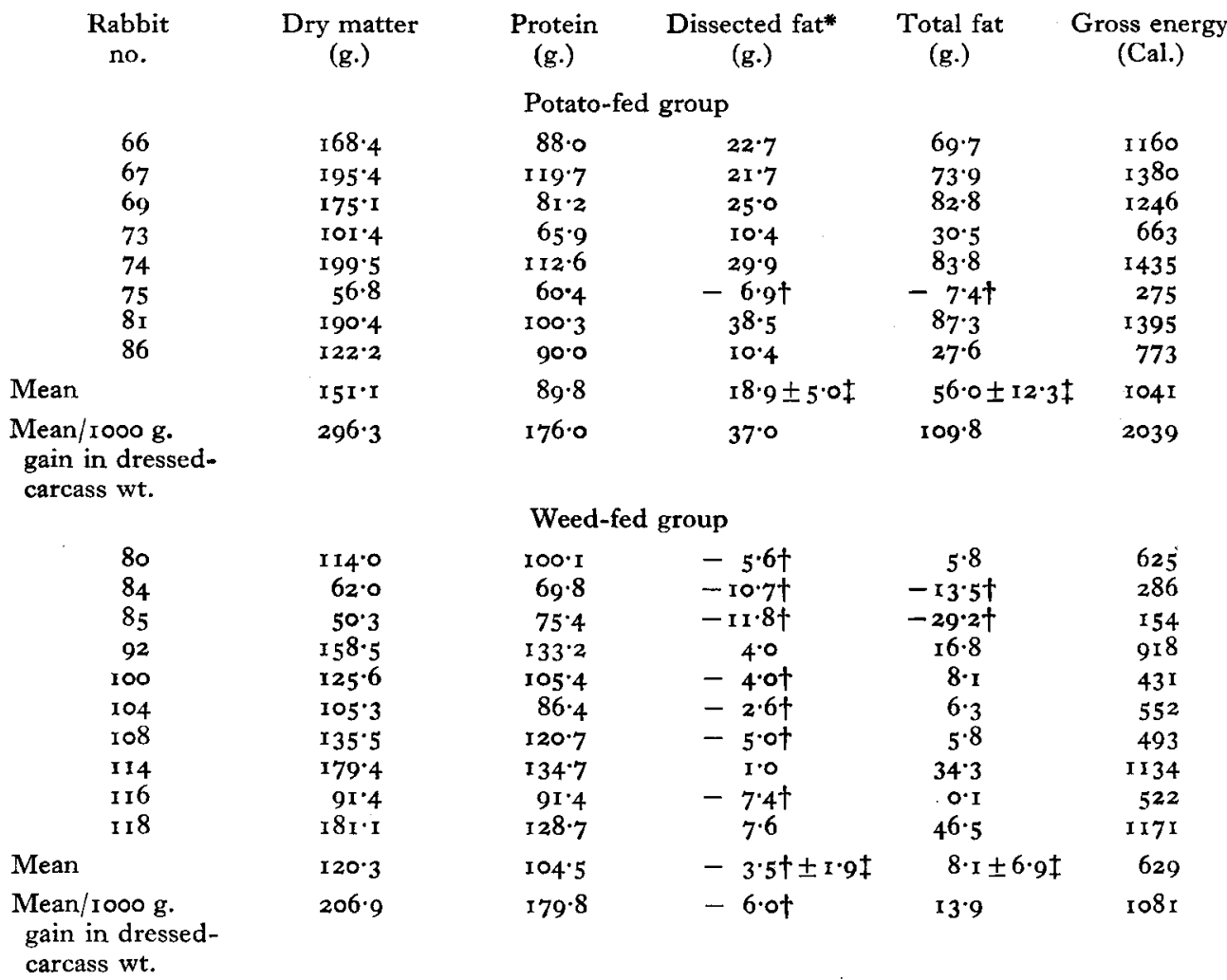

* Sum of kidney fat and fat removed from over the shoulders and the pubic region.

+ Negative sign denotes an estimated loss of fat.

\pm Standard error of the mean.

the carcasses of the potato-fed group contained 3-4 times as much of this fatty tissue as those of the weed-fed group. Rabbit no. 75 had coccidiosis from which it rapidly recovered but the disease may have affected fat deposition.

From the figures in Table 4 it may be seen that there was a very marked difference between the two groups in the quantity of edible fat and that the difference was greater in 'dissected fat' than in the total fat of the carcass. The fatty tissue round the kidney develops late in the rabbit. It seldom weighs more than $8 \mathrm{~g}$. in animals of this breed at 8 weeks old, but may weigh as much as $5^{\circ} \mathrm{g}$. at $\mathrm{I} 5$ weeks. Its deposition would, therefore, be particularly sensitive to dietary effects in an experiment of this nature. The edible dry matter of the carcasses of the potato-fed group was greater than that of the weed-fed group and the difference corresponds roughly to the difference in fat content. 
Protein deposition was, on the other hand, about the same in the two groups and there was no inverse relationship between the edible protein and fat deposited.

The difference in fat content resulted in a considerable difference in gross energy of the edible matter of the carcasses and, therefore, in the nutritive value for human consumption of the meat of the two groups.

Table 6. Relative weights of joints of carcasses of rabbits after removal of kidney fat, and of fat from over the shoulders and the pubic region, expressed as a percentage of total weight

\begin{tabular}{|c|c|c|c|c|c|c|}
\hline $\begin{array}{c}\text { Rabbit } \\
\text { no. }\end{array}$ & $\begin{array}{l}\text { Pelvis and } \\
\text { hindquarters }\end{array}$ & Fore-limbs & Loin & $\begin{array}{l}\text { Head and } \\
\text { neck }\end{array}$ & Thorax & $\begin{array}{c}\text { Tissue } \\
\text { covering } \\
\text { abdomen }\end{array}$ \\
\hline \multicolumn{7}{|c|}{ Potato-fed group } \\
\hline 66 & $33^{\circ} \circ$ & 12.9 & 19.0 & 14.8 & 13.7 & $6 \cdot 4$ \\
\hline 67 & $33 \cdot 7$ & $\mathrm{II} \cdot 8$ & $16 \cdot 3$ & 16.0 & $15^{\circ} 1$ & $7 \cdot 0$ \\
\hline 69 & $32 \cdot 8$ & $12 \cdot 1$ & $15 \cdot 9$ & $17 \cdot I$ & $14 \cdot 8$ & $7 \cdot 2$ \\
\hline 73 & $35 \cdot 3$ & $13 \cdot 1$ & $15 \cdot 5$ & I $5^{\cdot}$ I & $15 \cdot 3$ & $5 \cdot 6$ \\
\hline 74 & $33^{-2}$ & $11 \cdot 9$ & 16.7 & $15 \cdot 6$ & $15 \% 7$ & $6 \cdot 8$ \\
\hline 75 & $34 \cdot 3$ & 13.6 & $15 \cdot 9$ & $15^{\circ} 0$ & 15.4 & $5 \cdot 9$ \\
\hline $8 I$ & $34 \cdot 4$ & II 7 & $15 \cdot 8$ & 16.5 & $15 \cdot 1$ & $6 \cdot 4$ \\
\hline 86 & $35 \cdot 5$ & $12 \cdot 2$ & $16 \cdot 8$ & $16 \cdot 0$ & $13 \cdot 8$ & $5 \cdot 6$ \\
\hline Mean & 34.0 & $12 \cdot 4$ & I6.5 & 15.8 & $14 \cdot 8$ & $6 \cdot 3$ \\
\hline \multicolumn{7}{|c|}{ Weed-fed group } \\
\hline 80 & 343 & $12 \cdot 3$ & $17 \cdot 3$ & $\mathrm{r} 5 \cdot 3$ & $14 \%$ & $6 \cdot 3$ \\
\hline 84 & $34^{\circ} \circ$ & I3. 1 & 17.8 & 15.8 & 12.7 & $6 \cdot 5$ \\
\hline 85 & $34 \cdot 5$ & $12 \cdot 0$ & $16 \cdot 3$ & $16 \cdot 7$ & $14 \cdot 5$ & $6 \cdot 0$ \\
\hline 92 & $33 \cdot 8$ & $12 \cdot 9$ & 16.5 & 15.9 & $15 \cdot 3$ & $5 \cdot 6$ \\
\hline 100 & $34 \cdot I$ & 14.5 & $15 * 3$ & $16 \cdot 2$ & 13.5 & $6 \cdot 3$ \\
\hline 104 & $33 \cdot 5$ & $14 \%$ & 17.7 & $16 \cdot 1$ & $12 \cdot 5$ & 5.8 \\
\hline 108 & $32 \cdot 9$ & 12.5 & 18.3 & $16 \cdot I$ & 13.0 & $7 \cdot 1$ \\
\hline 114 & 35.5 & $12 \cdot 3$ & 16.6 & $14 \%$ & 15.0 & $6 \cdot 2$ \\
\hline 116 & 34.1 & 12.9 & $\mathrm{r} 7 \cdot 4$ & 14.4 & 15.4 & $5^{\cdot 6}$ \\
\hline 118 & $34^{\circ} \circ$ & 12.4 & 17.9 & 12.9 & 16.7 & $6 \cdot 1$ \\
\hline Mean & $34^{*}$ I & 12.9 & $17 \cdot 1$ & 15.4 & $14 \cdot 3$ & $6 \cdot 2$ \\
\hline
\end{tabular}

Comparison of the gains in edible matter during the feeding experiment (Table 5) shows a much more marked difference in the fat deposition of the two groups of animals. The weed-fed group produced hardly any fat at all. The average amount was one-seventh of that laid down by the potato-fed group. The difference was again greater in the 'dissected fat' than in the carcasses as a whole. The majority of the weed-fed group actually lost 'dissected fat'. Rabbits nos. 84 and 85 lost their entire store and yet these two animals made reasonably good growth.

From the carcass analyses it appears that the weed-fed group was less mature chemically than the potato-fed group. It is of interest to find out whether this difference in chemical maturity is correlated with any gross difference (other than deposition of depot fat) in anatomical maturity. Table 6 gives the weights of the joints of the carcasses, after removal of the 'dissected fat', expressed as a percentage of the sum of the weight of the joints. There are no significant differences between the two groups. From the measurements it appears that either chemical maturity does not run parallel with anatomical maturity or, more probably, that both groups of animals were anatomically mature (except in the deposition of fatty tissue) at the time of slaughter. 


\section{DISCUSSION}

It is demonstrated in these experiments that carcass fat in the rabbit as in other animals is not entirely dependent on the slope or shape of the growth curve. Carcass composition is of course affected by the rate of live-weight gain as Moulton et al. (r922), Vergés (1939) and McMeekan (1940 $a, b, c$ ) have shown, but the qualitative nature of the ration also has an important influence. It follows that the energy value of the meat in human nutrition cannot be assessed, even approximately, from live weight or dressed-carcass weight measurements. For example, the gross energy of the edible matter of the carcasses of the potato-fed group averaged $186{ }_{3} \mathrm{Cal}$., whereas that of the weed-fed group was ${ }_{3} 382$ Cal. If Rubner's factors for energy in human nutrition, namely $9.3 \mathrm{Cal} . / \mathrm{g}$. for fat and $4 . \mathrm{I} \mathrm{Cal} . / \mathrm{g}$. for protein, are applied, these figures become I 573 and ro95 Cal., respectively. Moreover, since the rate of growth and the shape of the growth curve of both lots of animals were approximately the same, energy content of the carcass cannot be predicted from a knowledge of the growth data.

The failure of the weed-fed group to lay down more fat was presumably due to the fact that, owing to the bulk of the ration, they did not receive from it enough metabolizable energy to cover their requirements. Moreover, since sow-thistle leaves contain only small quantities of starch and sugar, it is probable that most of the non-protein energy absorbed was in the form of fermentation products from cellulose, polyuronides and fructosans. It has not yet been shown that fat synthesis from these products is as easy as from glucose or from the products of fat digestion. The nature of the products of digestion as well as their gross energy may thus be an additional factor preventing fat synthesis. It will be shown in a later paper that addition of potatoes to the weed ration gives normal depot fat deposition but at the same time a somewhat greater growth rate. The potato-fed group considered in this paper presumably received enough metabolizable energy for the subnormal (three-quarters of the maximum) growth rate which they exhibited. Since these were ad hoc wartime experiments with natural rations it is not possible to specify the dietary deficiency which limited growth. Half of the animals received a supplement of casein, yet these animals did not grow much faster than the remainder and laid down just as much fat, so that a deficiency of protein is hardly likely to have been an important factor affecting growth or carcass composition; the protein level in the rations of the remainder of the group was, however, low. There were no macroscopic signs of rickets or any other abnormality in bone growth. It is possible, however, that the potato ration was deficient in folic acid or the 'grass juice factor'.

As the weeds contained about $85 \%$ of water, the weed-fed group was consuming considerably more water than the potato-fed group. This water, about $1000 \mathrm{~g}$./day, had to be warmed up to body temperature in the stomachs of the animals. This means that these animals were kept in an environmental temperature virtually lower than that in which litter-mates of the potato-fed group lived; this cooler climate might conceivably have required greater expenditure of energy to keep the weed-fed animals warm. On the other hand, roughly half of the potato-fed group was on experiment during the spring in an external climate on an average at least $10^{\circ} \mathrm{F}$. cooler than that 
during the summer, while all the weed-fed group was on experiment during the summer Furthermore, the latter group was generally within its zone of thermal neutrality at the time of day when it was feeding, and under these conditions it is improbable that subtraction from the animals' body of the heat necessary to warm the water in the weeds would increase the basal metabolism. Moreover, any such increase would be considerably reduced by utilization of a greater proportion of the heat increment of the ration to keep the animals warm (Swift, I944). It is unlikely, therefore, that the amount of heat required to warm the water to body temperature seriously reduced fat deposition.

It seems axiomatic that depot-fat production in growing animals must ultimately depend on the plane of energy nutrition, that is the supply of precursors of depot fat in excess of what is required for maintenance, and protein and bone production, because fat production, being less essential to the physiological needs of the animal, can only call on the food nutrients after the other needs of the body are satisfied. However, when dealing with more than one ration, one cannot assess this plane of nutrition in terms of growth rate and shape of growth curve or in terms of net or metabolizable energy related to body-weight. In the experiments described in this paper, although the rate of growth and shape of growth curve of the two groups were about the same, the plane of energy nutrition of the weed-fed group was virtually lower than that of the potato-fed group, either because the former did not receive sufficient gross digestible energy relative to the amount of muscle growth which the ration would support, or because the digestible energy was chemically unsuitable for synthesis of depot fat.

\section{SUMMARY}

I. Two groups of domestic rabbits were fed on a stock ration till weaning and thereafter for 7 weeks on a ration of weeds and of potatoes and hay, respectively. Some of the potato-fed group received a supplement of casein.

2. Growth rates and the shape of the growth curves throughout the life of the two groups were approximately the same. Growth during the 7 weeks' period of the feeding experiment was about three-quarters of the maximum.

3. The average dressed-carcass weights, killing out percentage and relative weights of joints of meat of the two groups were approximately the same.

4. The carcasses of the potato-fed group contained twice as much total edible chemical fat as those of the weed-fed group, and four times as much chemical fat round the kidney and over the shoulders and pubic region.

5. During the 7 weeks' feeding experiment the potato-fed group laid down seven times as much edible chemical fat as the weed-fed group. The animals in this group laid down a fair amount of fat round the kidney and over the shoulders and pubic region while the weed-fed group laid down none at all in these parts.

6. The edible protein content of the carcasses of the two groups was approximately the same.

7. It is concluded that the fat content, and therefore energy value, of rabbit meat for human nutrition cannot be assessed from the live weight or dressed-carcass 
weight, nor from a knowledge of the rate of growth or shape of growth curve, because fat deposition is profoundly influenced by the qualitative nature of the ration.

My thanks are due to Mr E. T. Halnan for advice and criticism and to Mr M. S. Pease at whose suggestion work on substitute rations for domestic rabbits was originally undertaken, and who provided accommodation for the animals at the Small Animal Breeding Station. I am also indebted to $\mathrm{Mr} \mathrm{C}$. J. Baker for carrying out many of the analyses and to Miss M. Thompson and Mr P. D. Bailey for care of the animals. The expenses of this work were in part defrayed by a grant from the Agricultural Research Council.

\section{REFERENCES}

Beadles, J. R., Quisenberry, J. H., Nakamura, F. I. \& Mitchell, H. H. (1933). 7. agric. Res. 47, 947. Breirem, K. (1935). Beretn. Forsøgslab. Kbh. no. I62.

Forbes, E. B., Swift, R. W., Black, A. \& Kahlenberg, O. J. (1935). F. Nutrit. 10, 46 r.

Forbes, E. B., Voris, L., Bratzler, J. W. \& Wainio, W. (I938). F. Nutrit. 15, 285.

Fraps, G. S. (1943). Poult. Sci. 22, 42 I.

Halnan, E. T. (1942). F. agric. Sci. 32, 179.

Hamilton, T. S. (1939). F. Nutrit. 17, 565 .

Johnson, S. R., Hogan, A. G. \& Ashworth, U. S. (1936). Res. Bull. Mo. agric. Exp. Sta. no. 246.

Kennard, D. C., Holder, R. C. \& White, P. S. (1922). Amer. F. Physiol. 59, 298.

McClure, F. J., Voris, L. \& Forbes, E. B. (1934). F. Nutrit. 8, 295.

McMeekan, C. P. (1940a). F. agric. Sci. 30, 276.

McMeekan, C. P. (1940b). F. agric. Sci. 30, $3_{87}$.

McMeekan, C. P. (1940c). F. agric. Sci. 30, 5 I I.

Mitchell, H. H. \& Hamilton, T. S. (1936). Proc. Amer. Soc. Anim. Prod. 1935, p. 24I.

Moulton, C. R., Trowbridge, P. F. \& Haig, L. P. (1922). Res. Bull. Mo. agric. Exp. Sta. no. 55.

Swift, R. W. (1944). 7. Nutrit. 28, 359.

Vergés, J. B. (1939). Yearb. Suffolk Sheep Soc. p. 27. 